\title{
Need Analysis of Basic Training Model of Forehand and Backhand Groundstroke Technique Based on Actions Method for Boys Aged 8-12 Years Old in Tennis
}

\section{(Development Study on Tennis Associations and Schools throughout D.I Yogyakarta Province)}

\author{
Ngatman Ngatman $^{1,2 *}$, M. Furqon Hidayatullah ${ }^{1}$, Sugiyanto Sugiyanto ${ }^{1}$, Sapta \\ Kunta Purnama ${ }^{1}$ \\ ${ }^{1}$ Sports Science Study Program, Faculty of Sports, Sebelas Maret University, Indonesia \\ ${ }^{2}$ Physical Education, Sports, Health and Recreations Study Program, Faculty of Sports Science, Yogyakarta State \\ University, Indonesia \\ *Corresponding author.Email:ngatman@uny.ac.id
}

\begin{abstract}
Forehand and backhand groundstroke is the most dominant technique used in tennis. These two techniques are the first basic techniques that are taught to children when they begin learning to play tennis. However, in fact, forehand and backhand groundstroke is the most difficult techniques for children to learn. The purpose of this study was to analyze the need for a basic forehand and backhand groundstroke training model based on an easy-to-learn action method for children. The method used in this research is descriptive analytic method using qualitative and quantitative approaches. The subjects in this study were coaches from tennis associations/schools who trained 10 children aged 8-12 years in the DIY Province. Questionnaires and structured interviews were used to collect the data. The qualitative data were analyzed by grouping the main ideas of the resource persons, while the quantitative data were analyzed using the percentage technique. This study was successful in identifying the various needs of tennis coaches in order to provide tennis instruction. These needs consist of: 1) the elements required for maximum tennis achievement, 2) the ideal tennis coaching process paradigm, 3) methods to hone ball feeling, ball control, and ball adjustment skills, 4) the need for appropriate training methods that can develop perception, decision, execution, and feedback, and 5) an action method through an open skill process that can develop the ability of perception, decision, execution, and feedback. The Actions method is expected to make teaching basic forehand and backhand groundstroke techniques to boys aged 8 to 12 years easier.
\end{abstract}

Keywords: Need Analysis, Training Model, Forehand and Backhand Groundstroke, Actions Method, Boys Age 8-12 Years.

\section{INTRODUCTION}

Field tennis is a sport that has complex motion characteristics. This is due to the fact that tennis is a sport that requires open motor skills. Open motor skills have the following characteristics: (1) the situation and conditions of the game that occur on the field are difficult to predict beforehand, (2) the situation and environmental conditions that occur are constantly changing, (3) players never make the same stroke twice, and (4) each stroke requires the player to go through a process: perception- 
decision-execution, and feedback [1]. Based on the characteristics of the tennis game, it is necessary to use teaching or training methods that are suitable with the game's characteristics when teaching or training children.

A tennis coach/teacher must have this basic knowledge and understanding of teaching/training methods that are in accordance with the characteristics of the tennis game. With this knowledge and understanding, it is hoped that the teacher/coach will be able to design appropriate training models according to the characteristics of the game and the abilities of the children to be trained with it. According to Crespo and Unierzyski (2007), the tennis teaching method that take into account the unique characteristics of the game will have several advantages, including: it will be a structuring catalyst in the application of strategies and tactics from the beginning of learning to play tennis, it can improve players' overall performance because it directly combines tactical awareness and the implementation of strategies and tactics, the tennis player's performing blows in decision-making are more accurate, has a higher level of specific knowledge than players who were trained using traditional methods [2]. This statement is also in line with what was conveyed by Wright, et. al., (2005) who said that teaching/training using a modification of the actual game situation would engage students cognitively, stimulate student interest, allow students to play more games, and give students the opportunity to transfer concepts from one game to another [5]. Based on this opinion, it can be concluded that having a method of teaching tennis based on an approach to the actual playing situation is critical. Students will be familiarized with teaching methods based on actual playing situations from the beginning they learn to play tennis, so they will always think critically before making decisions about the strokes they make. One of the methods of teaching tennis that can accommodate the demands of these characteristics is the actions method through the open skill / open training process.

Forehand and backhand groundstroke are the most difficult techniques for young children to learn, especially those aged 8-12 years, but in fact these two techniques are also the first basic tennis techniques to be trained/taught. Based on the author's experience as a Pelti Executive Board tutor/instructor at the National Tennis Coach Education "International Tennis Federation Level1 Coaches Course" in 2000 - 2019, tennis coaches/instructors frequently find it difficult to train forehand and backhand groundstrokes. According to the findings of these observations, the problems faced by the coaches include a lack of technical ability to play tennis owned by the coach, a lack of competence of mastery of the coach's method in creating basic teaching techniques, understanding of the trainees' level of basic technical skills is not good, the knowledge and understanding of the coach on the models of basic technical exercises that correspond to the situation of playing tennis is still lacking, and the coach does not understand the movement ability's level of each trainees.

The author then observed the teaching-learning process towards several tennis associations in the Province of the Special Region of Yogyakarta to gain a more comprehensive understanding of the root of the problem. The author sees several trainers teaching/training forehand and backhand groundstroke techniques with the same drill model for all ages of tennis players (children, teenagers, adults, and the elderly) regardless of their level of basic technical ability, the training models provided to the trainees do not correspond to the actual tennis situation; when the trainees performs forehand punches and backhand groundstrokes, the percentage of failure remains very high (for example: from 10 times the chance of doing the second punch of the basic technique of the ball that goes into the field on average 2-4 times, the rest of the balls hit are stuck to the net or off the field).

Exploring some of these issues, the researchers went on to conduct a needs analysis by distributing questionnaires and conducting interviews with several coaches at tennis associations or schools in the Province of DIY. The following outcomes are obtained from the needs analysis snippet: (a) new method innovations are needed to teach basic forehand and backhand groundstroke techniques that are in accordance with real tennis playing situations, particularly for children aged 8 12 years. (b) training methods that can develop the ability of perception, decision, execution, and feedback in teaching the basic forehand and backhand groundstroke techniques based on the action method are required, and (c) a basic forehand and backhand groundstroke training model that is compatible with the trainees' characteristics and basic movement abilities is required.

Bompa (2009) stated that the development of multilateral movement is a fundamental concept of an exercise process, which is consistent with the results of the needs analysis [6]. Coaches should consider using multilateral movement training methods in the early stages of athlete development as a foundation for specialization and mastery of the sport. Training methods for multilateral movement development should be used especially when training children and juniors. In the development stage of children athletes and juniors, the elements of basic movement about physical and psychological attributes are very important to be developed. Natural movements such as running, jumping, climbing, and throwing are important skills during this phase of training. Bompa further said that the development of speed, agility, coordination, flexibility, and overall general fitness are important at this stage of development. In this process, young athletes will be taught various sports techniques, which include some developed sports techniques. The teaching model that 
prioritizes multilateral movement development will be based on the specialization training model for athletes. If we look closely, these natural basic movements (such as running, jumping and throwing) are widely used in court tennis, especially in forehand and backhand groundstrokes.

The results of Krasilshchikov's research (2013) concluded that the group of children who were given the multilateral training model and the group of children who were given direct training with branching specialization then the results of the two training models were compared to the quality of their physical fitness level, it turned out that the group that was trained with the multilateral training model treatment had a more significant level of physical fitness development than the group that was given the specialization model treatment directly [7].

Based on the opinion and reality of the actual motion in tennis, it can be concluded that how important multilateral movement is for children aged 8-12 years to learn the basic forehand and backhand groundstroke techniques. The enrichment of multilateral movement supplies will also greatly assist children aged 8-12 years in developing specific movements in learning other basic techniques as well as advanced techniques in the game of tennis.

The development of multilateral movement for children aged 8-12 years can simply be done through training models with open skill or open training systems. According to Magil and Anderson (2017) the training model with an open skill system is an exercise model where variables and environments are unpredictable during activities [8]. The success of open movement skills activities is largely determined by the level of behavioral adjustment to environmental changes. Adjustments must be made very quickly and respond effectively, and must have many different adjustment actions. One of the appropriate training methods to meet the demands of these criteria is the action method. The Actions method is a tennis teaching method that embeds two main frameworks, namely: apply "what to do (tactical)" and "how to do (technical)" for a tennis player (Crespo, 1998) [9]. Furthermore, Crespo (1998) said that actions method is a method of teaching tennis that provides a framework to integrate and develop each stage of the open skill process. The open skill process consists of: perception, decision, execution, and feedback. Actions method is a tennis teaching method that focuses on students (learned centered) by using tools, such as: problem solving through appropriate questions and guided discovery and the use of verbal cues and commands.

According to Turner (2003), the advantages of using the action method in teaching basic tennis techniques are: beginner tennis players, especially those under the age of 12 who are trained using the action method, have shown better performance in hitting punches and making decisions when playing tennis [10]. Furthermore, Turner said that teaching / training based on tactical games, tennis players will have a higher level of specific knowledge than players who are trained using traditional approaches. In line with this opinion, Zetou Eleni, et. al. (2014), said that a 12-year-old tennis player who is trained based on the real situation of playing tennis can apply simple tactics and strategies in the game of tennis, in addition developing the motor skills [11].

Based on the background description of the problem that has been described above, the author has the basic idea of research as a solution to solve these problems. As an answer to the above problems, the author conducted a Need Analysis Model of Basic Forehand and Backhand Groundstroke Techniques Based on Actions Method for Boys 8-12 Years Old in Tennis Games.

\section{METHOD}

This research is descriptive analytical research using qualitative and quantitative approach (mixed method). The data collection technique is done through structured interviews and giving questionnaires to the coaches of tennis associations throughout the province of DIY. The interview data is analyzed qualitatively by grouping the main ideas from the opinions of the resource persons. For quantitative data, it is analyzed using the percentage technique. The formula for analyzing research data from interviews results is as follows:

1) The formula for processing data per test subject

$$
\mathrm{P}=\frac{\mathrm{X}}{\mathrm{Xi}} \mathrm{X} 100 \%
$$

Information:

$\mathrm{P} \quad=$ Percentage of test subjects' evaluation results

$\mathrm{X}=$ Number of score answers by test subjects

$\mathrm{Xi}=$ Maximum number of answers in aspect assessment by test subjects

$100 \%=$ Constant

(Sugiyono, 2019).

2) The formula for processing the data as a whole test subject.

$$
\mathrm{P}=\frac{\Sigma \mathrm{X}}{\Sigma \mathrm{Xi}} \mathrm{X} 100 \%
$$

Information:

$\mathrm{P}=$ Percentage of overall evaluation results

test subject

$\Sigma \mathrm{X}=$ Total number of test subjects' answers in all aspects of the assessment

$\Sigma \mathrm{Xi}=$ Total maximum score of test subjects' in all aspects of the assessment 
$100 \%=$ Constant

(Sugiyono, 2019).

3) The formula for determining the percentage of total respondents

$\frac{\text { Total number of data scores }}{\text { number of respondents x number of question }}$ X 100\% items $\mathrm{x}$ total maximum score

(Sugiyono, 2019).

\section{RESULT AND DISCUSSION}

Tennis coaches at tennis associations in DIY have the same perspective on the elements that affect the maximum achievement of a tennis player's. These elements consist of: technique, tactics, physical, and mental. In providing training to trainees, these four elements must be integrated from the beginning in order to contribute to improving the achievements of tennis players aged 8-12 years.

The concept of long-term athlete development, including tennis, is a paradigm that the coaches agree with. However, in general, tennis coaches technically cannot describe in detail the target that are the goals at each level of long-term coaching based on the age group of players. Most coaches are still unable to describe the technical, tactical, physical, and mental components targets that will be applied from each stage in the longterm tennis coaching process. Similarly, the coach's perspective on the concept of long-term coaching in developing technical skills and applying simple tactics in tennis at learn to train stage.

The implementation of basic playing techniques for children aged 8-12 years is a very vital foundation for tennis players to develop advanced technical skills that are more complex. Thus, it is hoped that there will be no stagnation in the ability of tennis players above its age level. The development of playing tactics needs to be done at an early stage when children are trained to learn techniques for the first time. Familiarize the application of playing tactics will hone the thinking skills of children who train in the accuracy on making decision when playing or competing. The paradigm of the long-term athlete coaching concept in the opinion of the coaches stated that it was feasible to be applied to tennis players aged 8-12 years. The coaches think that long-term coaching can help athletes grow and also avoid the occurrence of earlier top achievement and the emergence of boredom in athletes.

According to the method used in tennis associations in the DIY Province to teach basic forehand and backhand groundstroke techniques for children aged 8 to 12 , states that $90 \%$ is not good, while $10 \%$ is good. As a result, a new breakthrough is required in order to get the best method to train both techniques to trainees.
Chart 1 , the methods used by tennis coaches is presented in chart 1.

Methods Used in Practicing Basic Forehand and Backhand Groundstroke Techniques for Tennis Players Ages 8-12

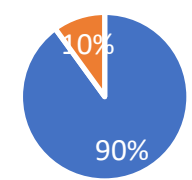

- Not Good Good

Chart 1. Methods Used by Tennis Trainers in DIY Province.

The condition of tennis coaching and training in DIY $80 \%$ said it was not good, $20 \%$ said it was good. Therefore, it is necessary to organize the coaching and training process to be more systematic and programmed.

\section{Tennis Coaching/Training Conditions in DIY Province}

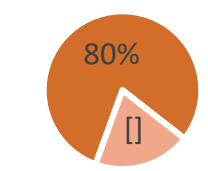

- Not Good - Good

Chart 2. Conditions of Guidance and Training in DIY Province.

Based on the results of the interview analysis of the need for training models to practice basic techniques forehand and backhand groundstroke-based actions method for children aged 8-12 years obtained the following results.

Table 1. Results of Interview

\begin{tabular}{|l|l|}
\hline \multicolumn{1}{|c|}{ List of questions } & \multicolumn{1}{|c|}{$\begin{array}{l}\text { Tennis } \\
\text { Coach } \\
\text { Answers }\end{array}$} \\
\hline $\begin{array}{l}\text { Does the trainer need a basic } \\
\text { forehand and backhand } \\
\text { groundstroke training model that } \\
\text { can train the ball feeling skills of the } \\
\text { trainees? }\end{array}$ & $\begin{array}{l}70 \% \text { Highly } \\
\text { needed, and } \\
30 \% \text { needed }\end{array}$ \\
\hline $\begin{array}{l}\text { Does the trainer need a basic } \\
\text { forehand and backhand } \\
\text { groundstroke training model that } \\
\text { can train the ball adjustment skills } \\
\text { of the trainees? }\end{array}$ & $\begin{array}{l}50 \% \text { highly } \\
\text { needed, and } \\
50 \% \text { needed }\end{array}$ \\
\hline
\end{tabular}




\begin{tabular}{|c|c|}
\hline $\begin{array}{l}\text { Does the trainer need a basic } \\
\text { forehand and backhand } \\
\text { groundstroke training model that } \\
\text { can train the ball control ability of } \\
\text { the trainees? }\end{array}$ & $\begin{array}{l}60 \% \text {, highly } \\
\text { needed, and } \\
40 \% \text { needed }\end{array}$ \\
\hline $\begin{array}{l}\text { Does the coach need a new method } \\
\text { that is easier and more fun for the } \\
\text { trainees' basic forehand and } \\
\text { backhand groundstroke techniques? }\end{array}$ & $\begin{array}{l}60 \% \text { highly } \\
\text { needed, and } \\
40 \% \text { needed }\end{array}$ \\
\hline $\begin{array}{l}\text { Does the trainer need a basic } \\
\text { forehand and backhand } \\
\text { groundstroke training model that } \\
\text { matches the characteristics of } \\
\text { children aged } 8-12 \text { years using a } \\
\text { tactical approach? }\end{array}$ & $\begin{array}{l}50 \% \text { highly } \\
\text { needed, and } \\
50 \% \text { needed }\end{array}$ \\
\hline $\begin{array}{l}\text { Does the trainer need a basic } \\
\text { forehand and backhand } \\
\text { groundstroke training model for } \\
\text { children aged } 8-12 \text { years using a } \\
\text { technical and tactical approach? }\end{array}$ & $\begin{array}{l}30 \% \text { highly } \\
\text { needed and } \\
70 \% \text { needed }\end{array}$ \\
\hline $\begin{array}{l}\text { Does the trainer need a basic } \\
\text { forehand and backhand } \\
\text { groundstroke technique training } \\
\text { model so that it can develop the } \\
\text { trainees' perception ability? }\end{array}$ & $\begin{array}{l}50 \% \text { highly } \\
\text { needed, and } \\
50 \% \text { needed }\end{array}$ \\
\hline $\begin{array}{l}\text { Does the trainer need a basic } \\
\text { forehand and backhand } \\
\text { groundstroke training model that it } \\
\text { can develop the trainees' decision- } \\
\text { making ability? }\end{array}$ & $\begin{array}{l}60 \% \text { highly } \\
\text { needed, and } \\
40 \% \text { needed }\end{array}$ \\
\hline $\begin{array}{l}\text { Does the trainer need a basic } \\
\text { forehand and backhand } \\
\text { groundstroke training model that } \\
\text { can develop the ability in the } \\
\text { execution of the trainees? }\end{array}$ & $\begin{array}{l}40 \% \text { highly } \\
\text { needed, and } \\
60 \% \text { needed }\end{array}$ \\
\hline $\begin{array}{l}\text { Does the trainer need a basic } \\
\text { forehand and backhand } \\
\text { groundstroke training model that } \\
\text { can develop the trainees' feedback } \\
\text { ability? }\end{array}$ & $\begin{array}{l}40 \% \text { highly } \\
\text { needed, and } \\
60 \% \text { needed }\end{array}$ \\
\hline $\begin{array}{l}\text { Does the trainer need a basic } \\
\text { forehand and backhand } \\
\text { groundstroke training model that } \\
\text { can develop the reception skills and } \\
\text { projection skills of the trainees? }\end{array}$ & $\begin{array}{l}50 \% \text { highly } \\
\text { needed, and } \\
50 \% \text { needed }\end{array}$ \\
\hline $\begin{array}{l}\text { Is there a need for a basic forehand } \\
\text { and backhand groundstroke training } \\
\text { model based on the Actions Method } \\
\text { that can develop trainees in } \\
\text { integrating their perception, } \\
\text { decision, execution, and feedback } \\
\text { abilities simultaneously? }\end{array}$ & $\begin{array}{l}50 \% \text { highly } \\
\text { needed, and } \\
50 \% \text { needed }\end{array}$ \\
\hline
\end{tabular}

\begin{tabular}{|l|l|}
\hline $\begin{array}{l}\text { Is it necessary to have the basic } \\
\text { forehand and backhand } \\
\text { groundstroke techniques training } \\
\text { model that match the actual tennis } \\
\text { game? }\end{array}$ & $\begin{array}{l}70 \% \text { highly } \\
\text { needed, and } \\
30 \% \text { needed }\end{array}$ \\
\hline $\begin{array}{l}\text { How is the trainer's willingness to } \\
\text { use the forehand and backhand } \\
\text { groundstroke basic technique } \\
\text { training model based on the Actions } \\
\text { Method which is predicted to } \\
\text { provide convenience and be able to } \\
\text { improve basic forehand and } \\
\text { backhand groundstroke technical } \\
\text { skills? }\end{array}$ \\
\hline
\end{tabular}

The summary of opinions, suggestions, input, and consideration of the results of the need analysis of the training model from tennis coaches in tennis associations/schools throughout the DIY Province who teach/train tennis players aged 8-12 years are: a) Tennis game is a sport that comes under the category of open skills, so the developed training model is adjusted to the characteristics of open skills. The model of basic training stages of forehand technique and backhand groundstroke-based actions method developed has been relevant and meets the criteria for the characteristics of open skills in tennis. b) Forehand and backhand groundstroke basic training models based on Actions Method through an open skill process are accepted as models to train children aged 8-12 years in tennis associations/schools throughout DIY Province. The stages in the training model have been designed to develop the ability of the trainees to perform: situation analysis and anticipation of the ball's trajectory, making decisions, hit the balls according to the decisions that have been made, and get feedback on the results of the strokes that have been made. These characteristics are the implementation of the open skill process in the actions method. c) The developed training model's stages correspond to the actual situation of playing tennis. By adapting the actual tennis game situation to the stages of the training model developed in the actions method, the trainees can avoid boredom and enjoy the training.

The paradigm of the concept of long-term athlete development for children aged 8-12 years is something that must be considered in order to develop their physical literacy. According to Addo, et. al., (2013) the overall development of children as well as the fundamental movement of motion skills, motion learning, and sports skills are priorities that must be done during the stages of children aged 12 years and under. A similar opinion was conveyed by Muhammad Furqon Hidayatullah (2019) who said that mastery of basic motion, basic movement skills, and basic sports skills allows children to read and 
make informed decisions, move confidently, and can control themselves in various situations of physical activity. Fort, et. al., (2011) said that the Long Term Development Athlete Model (LTAD) is an important concept that must be emphasized in coaching athletes regardless of the model used. The development program undertaken must have a holistic approach that includes several key interdisciplinary perspectives for the development of sport in general and the game of tennis in particular.

The use of teaching methods that can facilitate a trainees' ability to practice in practicing basic forehand and backhand groundstroke techniques for tennis players aged 8-12 years must be available. The use of traditional/conventional tennis training methods at this time is no longer relevant to the trend of modern tennis games. This agrees with Jigang and Song (2014), who claim that traditional tennis teaching methods are incapable to adapt with sports and social education needs that are increasingly changing with the times. The coaches should implement the theory of multiple intelligences in the teaching of tennis, conduct a variety of teaching content combined with teaching objectives, strengthen the development of student's psychological quality, while at the same time improving the physical quality to ensure the student's overall development. Thus, it is necessary to renew tennis teaching methods in order to facilitate the learning of children to train so that basic techniques forehand and backhand groundstroke become easier and fun.

The need for an exercise model that matches the characteristics of the actual sport is indispensable. Turner and Martinek's (1999) study found that a real game-based teaching model can actually facilitate the development of declarative, procedural and tactical decision-making knowledge, forming the game to determine the various tactics and skills needed to success, and become a reference point to help children learn making the right tactical decisions. According to the findings of Turner, et al., (2002), teaching tennis to children aged 12-14 years using the Game for Understanding (GFU) approach can provide an understanding of the overall dynamics in tennis game, the ability to adapt a variety of skills learned into various situations and conditions of the game, and the child will have declarative and factual informative knowledge.

When developing a basic forehand and backhand groundstroke model for children, ball feeling, ball control, and ball adjustment are very important elements to develop. These three abilities are used as a basis to train the reception skills and projection skills of the trainees. Reception skills and projection skills can be developed through an action method-based training model. The Actions method provides a framework for integrating and developing each stage of the open skills process. The open skill process consists of: perception, decision, execution, and feedback (Cayer, 1988).

The training model to sharpen perception, decision, execution, and feedback skills must be trained on trainees from the beginning they learn basic forehand and backhand groundstroke techniques. This is based on the fact that these abilities will always be encountered by trainees when playing/competing tennis. Therefore, the four stages of the open skill process from this action method must be gradually taught through training models so that the children learn to play tennis intelligently.

Actions method is a method of teaching tennis centered on students through the use of assistive devices, such as: problem solving, proper questions, and guided discovery like the use of sign language and giving commands by using words in the training process. According to Novick (1988) the form/feature of the action method-based teaching method has the following characteristics: (1) a student-centered approach to tennis teaching based on the development of open skills, (2) a tactical framework (what system to do), and (3) an engineering framework (how the system is done). It encourages children to adapt and make quick decisions in response to changing and unpredictable environmental conditions during the training process. The environmental conditions referred to include: wind direction, sunlight, the circumstances around the place, altitude, weather, surface of the place or field, sound and match opponents.

The development of this training model is predicted to provide convenience, excitement, and avoid boredom for training children in learning basic forehand and backhand groundstroke techniques. Thus, the tennis coaches throughout DIY agreed to use this action method as a method to train the basic forehand and backhand groundstroke techniques for boys aged 8-12 years.

\section{ACKNOWLEDGMENTS}

The author would like to thank Prof. Dr. M. Furqon Hidayatullah M.Pd., Prof. Dr. Sugiyanto, and Dr. Sapta Kunta Purnama M.Pd., especially those who provided advice and guidance in the preparation of article. As well as tennis coaches at tennis associations/schools throughout the DIY province who assisted in collecting data for the analysis.

\section{REFERENCES}

[1] Addo, Richard S., Perez, J., \& Crespo, Miguel. 2013. Fundamental Motor Skilla for 10 and 12 Under Tennis Players (Coaching \& Sport Science Review). London: International Tennis Federation. 
[2] Amung Ma'mun dan Yudha M. Saputra. 1999. Perkembangan Gerak dan Belajar Gerak. Jakarta: Dirjen Dikdasmen, Depdikbud.

[3] Annarino, Anthony A., Cowell, Charles C., \& Hazelton, Helen W. 1980. Curicculum Theory and Design in Physical Education. London: The CV Mosby Company.

[4] Assosiation Tennis Professional Rank (diakses 7 Januari 2020 pukul 13.30 WIB dari: https://www.atptour.com/en/rankings/singles).

[5] Balyi, Istvan. 2001. Sport System Building and Long-Term Athlete Development in British Columbia. P.E. Journal. University of Limerick, Ireland, $6-10$.

[6] Balyi. I, Way. R. Rosenburg, K. Grove.J, \& Robilliard, B. 2012. Canadian Sport for I Life: An Introduction Physical Literacy (Van Couver Canada).

[7] Balyi, I., Way. Richard, \& Colin, H. 2013. LonTerm Athlete Development. Champaign, Illionis: Human Kinetics.

[8] Baumgartner, T.A., Jackson, A.S., Mahar, M.T., \& Rowe, D.A. 2007. Measurement for Evaluation in Physical Education \& Exercise Science (Eight Edition). New York: McGraw-Hill.

[9] Bey Magethi. 1990. Tenis Para Bintang: Bandung: Pionir Jaya.

[10]Bloom, B. 1985. Developing Talent in Young People. New York: Ballantine Books.

[11]Bompa, Tudor O. 1999. Theory and Methodology of Training. The Key to Aathletic Performance, 4rd Edition Dubuque Iowa: Kendall/Hunt Publishing Company.

[12] Bompa, Tudor O. 1999. Periodization (Theory and Methodology of Training) Fourth Edition. USA: Human Kinetics.

[13]Bompa, O. Tudor., \& Haff, Gregory. G. 2009. Periodization Theory and Methodology of Training Champaign. ILHuman Kinetic.

[14]Bompa, O. Tudor., \& Carrera, Michael. 2015. Conditioning Young Athletes, Canada: Human Kinteics
[15]Borg, R. Walter., \& Gall, D. Meredith. 2003. Education Research. New York. Interstate Book Manufactures.

[16] Machar Reid, Ann Quinn, \& Crespo, M. 2003. Strength and Conditioning for Tennis. London: International Tennis Federation Ltd.

[17]Brown, Jim. 1996. Teaching Tennis Step to Success. Champaign, Illinois: Leisure Press.

[18]Bum Lee Seung. 2017. The Influence of the Technical and Physical Fitness Factors on Tennis Player's Performances (International Journal of Advances in Science Engineering and Technology). ISSN: 2321-9009 http://iraj.in.

[19] Cam, I., Bulut T., \& Zeynep, O. 2013. The Analysis of The Last Shots of The Top level Tennis Players in Open Tennis Tournaments. "Turkish Journal of Sport and Exercise," Vol.15, 2013, h. 54-57.

[20] Cayer, Louis. 1988. Mini Tennis/Novice Tennis Instructor. Canada: National Coaching Certification System.

[21] PELTI, PB. 1996. Actions Method. Seminar Pelatih PELTI. Yogyakarta: Pengurus Besar PELTI.

[22] Corbin, Charles B. 1980. A Texbook of Motor Development 2nd Edition. Dubuque, Iowa: Wm C. Brown Company Publishers.

[23] Côté, J., Baker, J., \& Abernethy, B. 2007. Practice and Play in The Development of Sport Expertise. In G. Tenenbaum \& R. Eklund (Eds.), Handbook of sport psychology (3rd ed., pp. 184-202). Hoboken, NJ: Wiley.

[24] Crespo, Miguel. \& Miley, Dave. 1998. Advanced Coaches Manual. Bank Lane, Roehampton, London: International Tennis Federation.

[25] Currell, K. \& Jeukendrup, A. E. 2008. Validity, Reliability and Sensitivity of Measures of Sporting Performance. Sport Medicine, 38(4), 297-316.

[26]Dave, Miley \& Doug MacCurdy. 1998. Coaches Manual. Canada: ITF Coaches Commission.

[27]Douglas, Paul. 1992. The Handbook of Tennis (Fully Revised Edition). England: Pelham Books.

[28] Elliot, Bruce. 2006. "Biomechanics and Tennis" (Brithis Journal and Sport Medicine, May 2006; v. 40.5). 
[29] Engstrom, Lars-Magnus., Forsberg, Arthur \& Apitzsch, Erwin. 1989. Coaching Children and Young People in Tennis. Philadelphia, PA: Saunders College Publishing.

[30]Ford, P., De Ste Croix, M., Lloyd, R., Meyers, R., Moosavi, M., Oliver, J., \& Williams, C. 2011. The Long-Term Athlete Development Model: Physiological Evidence and Application. Journal of Sports Sciences, 29(4), 389-402.

[31] Gallahue, David L. 1989. Understanding Motor Development Infant, Children, Adolecent. New York: MacMillan Publishing Company.

[32] German Tennis Association. 1995. Tennis Course Volume 1 Techniques and Tactics. Munich: BLV Publishing. Inc.

[33] González, R. \& Ochoa, C. 2003. "Working with Special Populations - Children, Females, Veterans and Wheelchair. Part I: Children - Physical Activity and Performance", In A. Quinn, M. Reid, \& M. Crespo (Eds.). Strength and Conditioning for Tennis (pp. 187- 192). London: ITF Ltd.

[34] Handono Murti. 2002. Tenis Sebagai Prestasi dan Profesi. Jakarta: Tyas Biratno Pallal.

[35] Harrow, Anita J. 1977. A Taxonomy of the Psychomotor Domain. New York: David McKay Company, Inc.

[36] Harsono. 2015. Kepelatihan Olahraga Teori dan Metodologi. Bandung: Rosda Karya.

[37] Hendro Kusworo. 2010. Pembelajaran Forehand Groundstroke serta Kekuatan Otot Bahu Bagi Petenis Pemula (Thesis). Surabaya. Pascasarjana Unesa.

[38] Hohm, Jindrich \& Klavora, Peter. (1987). Tennis, Technique and Tactics: Play to Win the Czech Way. Toronto, Canada: Sport Book Publishers.

[39] Horne \& Keown. 2015. Groundstroke Tennis Drill eBooks. (www.eBooks Author Academy.com Global Tennis Coaching.com, 2011), (diakses 26 Desember 2018), h.10.

[40]Huber, Jeffery. 2013. Applaying Educational Psychology in Coaching Athlete. USA: Human Kinetics an Employee.
[41] Hume, Joice. 1986. Play Better Tennis. London Pelham Books.

[42] Hurlock, Elizabeth B. 1978. Child Development. Auckland: McGraw-Hill.

[43] Ibrahim Cam, Bulut Turhan, \& Zeynep Onag, 2013. The Analysis of The Last Shots of The Top level Tennis Players in Open Tennis Tournaments. (Turkish Journal Of Sport And Exercise, Vol.15)

[44] International Tennis Federation. 1999. Teaching Methodology for Tennis. ITF Coaches Review, 19, 3-4. Ltd. London.

[45] King, Billie J. 1996. Rahasia Sang Juara. Semarang: Dahara Prize.

[46] Kolman, Nikki S., Tamara Kramera, Marije T. Elferink-Gemsera, Barbara C. H. Huijgena, \& Chris Visscher. 2018. Technical and Tactical Skills Related to Performance Level in Tennis: A Systematic Review. Journal of Sports Sciences, 2018 https://doi.org/10.1080/02640414.2018.1483699. London: Informa UK Limited, trading as Taylor \& Francis Group.

[47] Krasilshchikov Oleksanddr. 2013. Effect of Short Term Multilateral and Sport Specific Training on Physical Fitness Profile of Malaysia School Children,". International Journal of Research Padagogy and Technology in Education and Movement Science, Vol.1 (3) March 2013, hh.3040 .

[48]Kutlu, M., Yapici, H., \& Demirkan, E. 2014. Reliability and Validity of New Test on Agility and Skill for Children Soccer Players. Central European Journal of Sport Science and Medicine, 6(2), 5-12.

[49]Larson, Emma J., Guggenheimer, \& Joshua D. 2013. The Effect of Scaling Tennis Equipment on The Forehand Groundstroke Performance of Children (Journal of Sport Science and Medicine). 12, 323-331. Diakses dari: http://www.jssm.org.

[50] Magil, Richard A. dan Aderson, David I. 2017. Motor Learning and Control: Concepts and Aplications. Eleventh Edition. Dubuque: Mc GrawHill Education.

[51] Marten, Rainer. 1990. Successful Coaching (United States Tennis Association Special Edition). United States of America: Human Kinetic Publishers. 
[52] M.E. Winarno. 1994. Belajar Motorik. Malang: Depdikbud, IKIP Malang, Proyek Operasi dan Perawatan fasilitas.

[53]M. Furqon Hidayatullah. 2019. Aktivitas Gerak Pada Masa Kanak-Kanak (Cetakan Ketiga). Solo: Cakrawijaya.

[54] Miley, Dave. (1998). ITF Level I Coaches Manual. London: International Tennis Federation.

[55] Morrow, J.R., Jackson, A.W., Disch, J.G., \& Mood, D.P. (2005). Measurement and Evaluation in Human Performance (Third Edition). United States of America: Human Kinetics.

[56] Nana Sudjana. 2010. Penilaian Hasil Proses Belajar Mengajar. Bandung: PT Remaja Rosda Karya.

[57] Ngatman. 2001. Action Methods Dalam Tenis Lapangan (Tabloit Tennis). Jakarta: Pengurus Besar PELTI.

[58] Ngatman, N. 2020. Teknik-Teknik Dasar dan "Actions Method" Dalam Tenis (Cara Efektif Mengajar dan Melatih Tenis Tingkat Pemula). Yogyakarta: UNY Press.

[59] Novick, Ari. 1988. Coach 1 Assistant Coach (The Actions Method). Canada: National Coaching Certification Program.

[60] Coaching Association of Canada. 1988. Coach 2 Club Level Coach (The Actions Method). Canada: National Coaching Certification Program.

[61] Ochi, S., \& Campbell, M. J. 2009. The Progressive Physical Development of A Hight Performance Tennis Player. Strength \& Conditioning Journal, 31(4), 59-68.

[62] Ochi, S., \& Kovacs, M. S. 2016. Periodization and Recovery in the Young Tennis Athlete. In the Young Tennis Player (pp. 87-104). Springer International Publishing.

[63] Pankhurst, Anne. 2013. How Tennis Players Learn Motor Skills: Some Consideration (ITF Coaching and Sport Science Review 2013; 60 (21): 6-7. United Kingdom: International Tennis Federation.

[64] Paul, Roetert E. \& Kovacs, Mark S. 2011. Tennis Anatomy. United States Tennis Assosiation: Human Kinetics Publishers.
[65] Potop.V. 2013. Influence of Sensory Motor Coordination on The Technical Training in Woman Artistic Gymnastic, (Journal Buletin Transilvania University of Brasov.Series IX: Science of Human Kinetics.Vol.6. 55. 2013), h. 4.

[66]Pyke, Frank. S. 1991. Better Coaching: Advanced Coach's Manual. Australia: Australian Coaching Council Incorporation.

[67] Randy Hyllegard. 1991. Pendekatan Tiga Macam Keterampilan Untuk Tenis (Majalah Tenis, Edisi Januari 1991). Jakarta: Pengurus Besar PELTI.

[68]Reid, M., Lay, B., Crespo, M., \& Barry, J. 2007. Skill Acquisition in Tennis: Research and Current Practice. Journal of Science and Medicine in Sport, (2007) 10,1-10. Elsevier.

[69] Rex Lardner. 1987. Teknik Dasar Tenis (Strategi dan Teknik Yang Akurat). Semarang: Dahara Prize. (terjemahan).

[70] Riduwan. 2014. Dasar-Dasar Statitika. Bandung: Alfabeta.

[71] Schmidt, Richard A. 1988. Motor Control and Learning. Champaign: Human Kinethics Publisher Inc.

[72] Schmidt, Richard A., \& Lee, Timoty D. 2005. Motor Control and Learning A Behavioral Emphasis 5th Edition. (diakses dari: https://www.amazon.com/Motor-ControlLearning-Behavioral Emphasis/dp/0736079610, Tanggal 28 April 2020, Pukul 20.40 WIB).

[73] Sharkey, Brian J. \& Gaskil, Steven E. 2006. Sport Physiologi of Coaches (Principles of Training). Montana University, USA: Human Kinetics Publishers.

[74] Singer, Robert N. 1980. Motor Learning and Human Performance an Aplication to Motor Skills and Movement Behaviors (Thir Edition). New York: Macmillan Publishing Co., Inc.

[75] Soediharso. 1991. Buku Materi Pendidikan Pelatih Tenis Tingkat dasar PELTI. Jakarta: PB PELTI.

[76] Strand, Bradford N. \& Wilson, Rolayne. 1993. Assesing Sport Skills. United State of America: Human Kinetics Publishers. 
[77] SPARC. 2012. Developing Fundamental Movement Skills. (Sport New Zealand: www.sparc.org.nz).

[78] Sugiyanto. 2003. Perkembangan dan Belajar Motorik. Jakarta: Pusat Penerbitan Universitas Terbuka, Departemen Pendidikan Nasional.

[79] Sugiyono. 2009. Metode Penelitian Kuantitatif Kualitatif \& R\&D. Bandung: Alfabeta.

[80] Sugiyono, S. 2014. Metode Penelitian Kuantitaif Kualitatif Dan R \& D. Bandung: Alfabeta.

[81] Sugiyono, S. 2019. Metode Penelitian \& Pengembangan Research and Development Untuk Bidang: Pendidikan, Manajemen, Sosial, Teknik. Bandung: Alfabeta.

[82] Sukadiyanto. 1996. Permainan Tenis Salah Satu Wahana Membina Remaja Untuk Berprestasi dan Berkepribadian (Cakarawala Pendidikan Edisi Desember 1996). Yogyakarta: Universitas Negeri Yogyakarta.

[83] Sukadiyanto, dan Dangsina Muluk. 2011. Pengantar Teori dan Metodologi Melatih Fisik. Bandung: Lubuk Agung.

[84] Syahrial, Bakhtiar dan Robert John Ballard. 2015. Teori Actions Method, Strength Condition, dan Penerapannya dalam Pembinaan Prestasi Tenis. Malang: Wineka Media.

[85] Tennis Canada Coaching Certification System. 1988. Mini Tennis/Novice Tennis Instructor. Canada: National Coaching Certification Program.

[86] Tennis Canada. 2003. Long Term Athlete Development Plan for the Sport of Tennis in Canada. (Coaching \& Sport Science Review). London: International Tennis Federation.

[87] Tony Mottram. 1992. Fundamental Tenis Resep Meraih Kemenangan. Semarang: Dahara Prize.

[88] Tsetseli, M., Mallaiou. V, Zetou. E, Michalopouou. M, Kambas. A. 2010. The Effect of Coordination Training Development of Servis Tennis Technique, (Journal Biology of Exercises, Vol. 6. 1. 2010), h. 31.

[89] Tsetseli, M., Zetou, E., Vernadakis, N., \& Michalopoulou, M. 2016. The Effect of Internal and External Fokus Attention on Game Performance in
Tennis. Acta Gymnica, Vol. 46, no 4, 2016, 162173.

[90] Turner, A. 2003. A Comparative Analisis of Two Approach for Teaching Tennis: Game Based Approach Versus Technique Approach. Paper Presented at the 2 nd ITF Tennis Science and Technology Congress. London.

[91] United States Tennis Association. 1996. Tennis Tactics: Winning Patterns of Play. Champaign, Illinois: Lelsure Press.

[92] Unierzyski, Piotr \& Crespo Miguel. 2007. Review of Modern Teaching Methods for Tennis. (International Journal of Sport Science) Vol. III Ano III (diakses dari: http://www.cafyd.com/REVISTA/00701.pdf

[93] Vincent, William J. 1996. Statistics in Kinesiology. Champaign, Illinois. Human Kinetics.

[94]Williams, Scott. 2000. Serious Tennis. United States of America: Human Kinetics Publishers.

[95] Wright, Steven, Mc Neillb, Michael, Joan Fryb, \& Wang John. 2005. Teaching Teachers to Play and Teach Games. Physical Education and Sport Pedagogy. Vol. 10, 1, 61-82.

[96]Zetou, Eleni., Evangelos, Nikolas, Vernadakis., Vassiliki, Derri., Evangelos, Bebetsos., \& Fiippos Filippou. 2014. The Effect of Game for Understanding on Backhand Tennis Skill Learning and SelfEfficacy Improvement In Elementary Students. (Procedia-Social and Behavioru Sciences, $\mathrm{h}$. 765-771). Komotini, Greece. Elsevier. 